Zeszyty Naukowe Szkoły Głównej Gospodarstwa Wiejskiego w Warszawie

Problemy Rolnictwa Światowego tom 18 (XXXIII), zeszyt 3, 2018: 295-305

DOI: $10.22630 /$ PRS.2018.18.3.87

Sebastian Stępień $^{1}$, Marta Guth ${ }^{2}$, Katarzyna Smędzik-Ambroży ${ }^{3}$

Uniwersytet Ekonomiczny w Poznaniu

\title{
Rola wspólnej polityki rolnej w kreowaniu dochodów gospodarstw rolnych w Unii Europejskiej w kontekście zrównoważenia ekonomiczno-społecznego ${ }^{4}$
}

\section{The Role of the Common Agricultural Policy in Creating Agricultural Incomes in the European Union in the Context of Socio-Economic Sustainability}

\begin{abstract}
Synopsis. Celem publikacji jest określenie wpływu subsudiów wspólnej polityki rolnej (WPR) na poziom ekonomicznego i społecznego zrównoważenia gospodarstw rolnych w krajach Unii Europejskiej. Zakres przestrzenny obejmuje wszystkie kraje UE, a zakres czasowy lata 2005-2015. Główna konkluzja stanowi, iż dzięki wsparciu w ramach WPR średnie dochody gospodarstw rolnych zbliżają się do przeciętnych dochodów w sektorach pozarolniczych, jednak dystrybucja wsparcia dla gospodarstw rolnych jest nierówna względem ich siły ekonomicznej. To prowadzi do wzrostu dysparytetu dochodów pomiędzy małymi, średnimi i dużymi podmiotami. Innymi słowy, unijna polityka rolna poprawia ogólny poziom zrównoważenia ekonomicznego rolnictwa, ale nie spełnia kreterium zrównoważenia społecznego ( $\mathrm{w}$ tym ujęciu rozumianego przez pryzmat bardziej równomiernej dystrybucji dochodów). Z tego punktu widzenia można stwierdzić, iż wsparcie rolnictwa $\mathrm{w}$ ramach WPR powinno być kontynuowane, aby zapobiec deprywacji dochodów rolniczych względem otoczenia, jednakże struktura tego wsparcia musi być zmieniona w kierunku bardziej sprawiedliwego podziału funduszy.
\end{abstract}

Słowa kluczowe: wspólna polityka rolna, subsydia, zrównoważenie ekonomiczno-społeczne, dochody rolnicze, kraje UE.

\begin{abstract}
The aim of the paper is to determine the influence of the Common Agricultural Policy's (CAP) subsidies on the level of economic and social sustainability of farms in the European Union countries. Spatial scope covers all EU countries and the time range covers the years of 2005-2015. The main finding is that, thanks to the CAP support, the average income of farm households is approaching the average income of non-agricultural sectors, but distribution of this support is uneven among the farms. This leads to an increase in income disparities for small, medium and large farms. In other words, the EU's agricultural policy improves the general level of economic sustainability of the agricultural sector, but it is not an instrument serving the income equilibrium (as a social element of sustainability). From the point of view of the sustainable development paradigm, support for agriculture should be continued to prevent deprivation of agricultural income in relation to nonagricultural income. However the structure of CAP support should be changed towards a more equable distribution of money, as it now leads to differentiation of income of small and large farms.
\end{abstract}

\footnotetext{
${ }^{1}$ dr hab., prof. nadzw. UEP, Katedra Makroekonomii i Gospodarki Żywnościowej, Uniwersytet Ekonomiczny w Poznaniu, Al. Niepodległości 10, 61-875 Poznań; e-mail: sebastian.stepien@ue.poznan.pl; https://orcid.org/0000-0001-9475-8418

${ }^{2}$ dr, e-mail: marta.guth@ue.poznan.pl; https://orcid.org/0000-0001-9332-1193

${ }^{3}$ dr, e-mail: katarzyna.smedzik-ambrozy@ue.poznan.pl

${ }^{4}$ Artykuł powstał w ramach grantu badawczego pt. „Determinanty bezpieczeństwa żywnościowego i zrównoważonego rozwoju drobnotowarowych gospodarstw rolnych w Polsce na tle regionów Unii Europejskiej”, finansowanego przez Narodowe Centrum Nauki (umowa nr 2016/21/B/HS4/00653).
} 
Key words: Common Agricultural Policy, subsidies, economic and social sustainability, farm incomes, panel analysis, EU countries.

JEL codes: Q10, Q12, Q18, E6, H2, P16

\section{Wprowadzenie}

Pojęcie zrównoważenia społeczno-ekonomicznego (lub rozwoju zrównoważonego pod względem ekonomicznym i społecznym) jest bardzo obszerne i w zależności od przyjętej koncepcji wymienia się różne cechy opisujące ten stan. Ogólnie przyjmuje się, że rozwój zrównoważony łączy $\mathrm{w}$ sobie potrzeby realizacji potrzeb obecnej generacji bez ograniczania praw przyszłych pokoleń do zaspokajania ich aspiracji. W odniesieniu do rolnictwa koncepcja zrównoważonego rozwoju zakłada jednoczesne dążenie do poprawy warunków życia ludności i prowadzenia działalności gospodarczej na obszarach wiejskich, przy nienaruszaniu specyficznych zasobów wsi, takich jak środowisko naturalne, krajobraz i dziedzictwo kulturowe. Warunkiem koniecznym takiego rozwoju staje się dążenie do sytuacji, w której dochody i jakość życia rolników i innych mieszkańców wsi są porównywalne do tych uzyskiwanych w działach pozarolniczych. Ważne jest także, aby beneficjentem zmian była możliwie szeroka grupa producentów rolnych, co wymaga sprawiedliwego podziału owoców wzrostu.

Koncepcja zrównoważonego rozwoju staje się coraz częściej elementem strategii politycznych. Szczególnie widoczne jest to na poziomie Unii Europejskiej, dla której współczesna wizja tej idei obejmuje takie priorytety, jak: rozwój inteligentny, oparty na wiedzy i innowacjach, rozwój sprzyjający włączeniu społecznemu, przy wysokim poziomie zatrudnienia i zapewnieniu spójności społecznej i terytorialnej, a także rozwój przy wsparciu gospodarki efektywniej korzystającej z zasobów, bardziej przyjaznej środowisku i bardziej konkurencyjnej. Warto jednocześnie podkreślić, że idea zrównoważonego rozwoju wymaga zintegrowanego podejścia na wszystkich szczeblach i we wszystkich politykach sektorowych. Przykładem jest wspólna polityka rolna, dla której jednym z głównych celów jest zagwarantowanie godziwego poziomu życia społeczności rolniczej, m.in. poprzez stabilne dochody i poprawę warunków funkcjonowania na obszarach wiejskich.

Celem artykułu jest określenie wpływu wspólnej polityki rolnej (WPR) na poziom zrównoważenia ekonomiczno-społecznego gospodarstw rolnych w krajach Unii Europejskiej (zrównoważenie środowiskowe jest przedmiotem osobnego opracowania). Autorzy stawiają hipotezę, że istniejące rozwiązania WPR służą osiąganiu zrównoważenia ekonomicznego (poprzez wzrost dochodów rolniczych względem pozarolniczych), nie zmniejszaja natomiast dysproporcji dochodowych wewnątrz sektora rolnego, co jest elementem zrównoważenia społecznego (nie oznacza to jednak, że nie poprawiają innych elementów tego zrównoważenia, takich jak poprawa warunków pracy czy dostęp do infrastruktury). Mówiąc inaczej, dzięki wsparciu średni dochód rolniczy gospodarstw zbliża się do przeciętnego dochodu z działów pozarolniczych, jednak pomiędzy gospodarstwami małymi, średnimi i dużymi dystrybucja tego wsparcia jest wysoce zróżnicowana. I chociaż w ujęciu absolutnym może następować poprawa jakości życia w każdej z wymienionych grup, to w rzeczywistości dochodzi do relatywnej deprywacji najmniejszych podmiotów. Wstęp do oceny oddziaływania polityki rolnej UE stanowi próba teoretycznego uzasadnienia wsparcia sektora rolnego w koncepcji ekonomii politycznej. W publikacji 
wykorzystano krytyczną analizę literatury przedmiotu, metaanalizę, metody wnioskowania indukcyjnego oraz elementy analizy szeregów czasowych. Zakres czasowy badań obejmuje lata 2005-2015, przestrzenny - kraje UE z podziałem na UE-15 i UE-8, zaś podmiotowy reprezentatywne gospodarstwa rolne EUFADN.

\section{Zrównoważenia społeczno-ekonomiczne rolnictwa w ekonomii politycznej}

Ekonomia polityczna jest współcześnie przedmiotem szczególnego zainteresowania ze względu na nowe zjawiska towarzyszące światu, a które mają kluczowy wpływ na funkcjonowanie społeczeństwa. Chodzi przede wszystkim o globalizację i finansyzacje gospodarek, które zakłócają działanie mechanizmu rynkowego i tworzą negatywne efekty zewnętrzne o charakterze ekonomicznym, społecznym i środowiskowym. Dotyczą one także funkcjonowania sektora rolnego (czy szerzej, żywnościowego), dlatego konieczne staje się poszukiwanie nowych kierunków rozwoju. Chodzi tu o wypracowanie modelu rozwoju rolnictwa trwale równoważonego, wspartego instytucjonalnie działaniami państwa. W Unii Europejskiej taką rolę pełni wspólna polityka rolna, kształtowana politycznie w procesie międzyrządowych uzgodnień, co pozwala ją oceniać przez pryzmat teorii wielopoziomowych negocjacji (multi-level bargaining theory) (Coleman i Tangermann, 1999; Paarlberg, 1997). Głównym dylematem staje się odpowiedź na pytanie o skuteczność mechanizmów interwencji w tworzeniu odpowiedniego standardu życia producentom rolnym. Taki był przecież pierwotny motyw tworzenia w latach 60 . jednolitej polityki rolnej Europejskiej Wspólnoty Gospodarczej i pozostaje on aktualny także w obecnych założeniach WPR (European Parliament, 2015, s. 11; Hill, 2012, s. 20; OECD, 2011, s. 22). Realizacja tego postulatu wymaga zaangażowania istotnej części łącznych wydatków budżetu UE, co spotyka się z krytyką ze strony zwolenników neoliberalnego podejścia do rozwoju sektora rolnego. Kierując się operatem racjonalności mikroekonomicznej przyjmują oni, że interwencjonizm państwowy (w naszym przypadku unijny) jest nieuzasadnionym przywilejem sektora żywnościowego i obciąża kosztami całe społeczeństwo (Rembisz, 2010; Stoeckel, 2000).

Zdaniem autorów, uwzględnienie perspektywy neoliberalnej w ocenie polityki rolnej jest nieuzasadnione, ponieważ nie uwzględnia specyficznych uwarunkowań rynku rolnego i czynnika ziemi, implikując nieefektywną alokację czynników wytwórczych. W tych warunkach rolnicy poddawani są ogromnej presji do zwiększania skali produkcji i koncentracji ziemi, co utrudnia pełnienie funkcji pozakomercyjnych (związanych $z$ dostarczaniem dóbr publicznych ${ }^{5}$ ) i powoduje negatywne efekty zewnętrzne o charakterze środowiskowym (Czyżewski i Stępień, 2017). Jednocześnie rynek, kierując się zasadą wyrównywania kosztów krańcowych, sprzyja tworzeniu silnych struktur oligopolistycznych, prowadząc do względnej deprywacji dochodowej słabszych ekonomicznie gospodarstw rolnych (Czyżewski i Poczta-Wajda, 2016; Dow i Reed, 2013). Efektem jest ciagłe utrzymywanie się dysparytetu dochodów rolniczych do pozarolniczych w warunkach wzrostu przeciętnego poziomu płac w gospodarce. Dzieje się tak dlatego, że w procesie kształtowania popytu pośredniego i końcowego rolnik uczestniczy w podziale

\footnotetext{
${ }^{5}$ Do takich zaliczyć można np. utrzymanie bioróżnorodności i walorów krajobrazowych, dbałość o tradycję i kulturę wiejską, dobrostan zwierząt, wysoką jakość żywności.
} 
wartości dodanej $\mathrm{w}$ stopniu nieadekwatnym. Wytworzona przez niego nadwyżka ekonomiczna nie spełnia w przepływach międzygałęziowych kryterium alokacji optymalnej i jest $\mathrm{w}$ dużej części przechwytywana przez skupujących, przetwórców, sprzedających, a w końcu samych konsumentów (Zegar, 2010; Czyżewski, 2007).

Następstwem opisanych wyżej zależności jest konieczność zwrócenia tej części wytworzonej nadwyżki ekonomicznej, która odpłynęła od producentów surowca. Wykorzystuje się w tym celu mechanizm redystrybucji dochodów do podatników, dawniej za pośrednictwem rynku (w latach 70. i 80. ceny minimalne i skup interwencyjny), dziś głównie budżetu, poprzez płatności bezpośrednie, subwencje inwestycyjne, ukierunkowane na ochronę środowiska i dostarczanie dóbr publicznych (Anania i Bartova, 2010; Josling i Anderson, 2017). Tego typu mechanizm wsparcia stanowi kompensację rynkowej dyskryminacji rolnictwa i jest ważną przesłanką dla kontynuowania wspólnej polityki rolnej UE (Zahrnt, 2011). Pojawia się potrzeba realizacji polityki rolnej motywowanej tymi negatywnymi konsekwencjami i wymogami społeczeństwa, z podkreśleniem roli UE oraz oznaczeniem pola wyboru politycznego z perspektywy interesów gospodarstw rolnych, mieszkańców wsi, a w końcu całego społeczeństwa zgodnie z zasadą zrównoważonego społecznie i ekonomicznie rozwoju (Czyżewski i Stępień, 2017). Prezentowane w kolejnych częściach publikacji badania wskażą, czy WPR w praktyce realizuje wspomniane wyżej cele.

\section{Metodologia badania}

W pierwszym etapie badań dokonano oceny wpływu dopłat z WPR na poziom dochodu reprezentatywnego gospodarstwa rolnego EUFADN ${ }^{6}$, przypadającego na osobę pełnozatrudnioną rodziny $\left(\mathrm{FWU}^{7}\right)$ względem średniego rocznego dochodu na osobę w gospodarce narodowej poszczególnych krajów należących do Unii Europejskiej. Zakres czasowy objął lata 2005-2015 (2004 rok był niepełny jeśli idzie o członkostwo krajów UE10). $Z$ analiz wyłączono Maltę i Cypr, ponieważ ani w statystkach OECD ani EUROSTAT nie zamieszczono danych odnośnie średniego rocznego wynagrodzenia $\mathrm{w}$ gospodarce narodowej, przypadającego na pełnozatrudnionego $\mathrm{w}$ tych krajach (jednak ze względu na niewielkie znaczenie sektora rolnego $\mathrm{w}$ tych państwach względem całej UE ich pominięcie nie powinno stanowić przeszkód $\mathrm{w}$ dalszym wnioskowaniu). Zestawienia dokonano z podziałem Unii Europejskiej na kraje UE-15 i UE-8 („nowe” państwa członkowskie bez Malty i Cypru). Dochód $\mathrm{z}$ reprezentatywnego gospodarstwa rolnego EUFADN, uwzględniający dopłaty z funduszy wspólnej polityki rolnej (suma dopłat do działalności operacyjnej oraz saldo dopłat i podatków do działalności inwestycyjnej), odniesiono do dochodu pozarolniczego. Założono, że wzrost takiej relacji w poszczególnych latach 20052015 powoduje wzrost zrównoważenia ekonomicznego rolnictwa w poszczególnych krajach UE, gdyż świadczy o polepszaniu się sytuacji dochodowej tego sektora względem

\footnotetext{
${ }^{6}$ System zbierania danych rachunkowych z gospodarstw rolnych z poszczególnych krajów członkowskich Unii Europejskiej. Dane te wykorzystywane są przy planowaniu, realizacji i ewaluacji zadań WPR. Gospodarstwa FADN reprezentują około $4 \mathrm{mln}$ gospodarstw rolnych w UE (por. http://ec.europa.eu/agriculture/rica/, data dostępu: 13.12.2017, http://ec.europa.eu/agriculture/rica/database/report_en.cfm?dwh=SO, data dostępu: 13.12.2017).

7 Jednostka przeliczeniowa pracy członków rodziny gospodarstwa rolnego (osób pełnozatrudnionych w gospodarstwie) (ang. Family Work Unit).
} 
pozostałych sektorów $\mathrm{w}$ danej gospodarce narodowej. Z kolei brak uwzględnienia wsparcia sprawiał, że na poziomie UE dochody rolnicze były ujemne, stąd nie było możliwości określenia relacji tych wielkości do dochodów pozarolniczych. W związu z tym obliczono rozpiętości (różnice absolutne) pomiędzy dochodami pozarolniczymi, a dochodami $\mathrm{z}$ rolnictwa, $\mathrm{w}$ wariacie $\mathrm{z}$ dopłatami $\mathrm{i}$ bez nich. $\mathrm{W}$ ten sposób można było potwierdzić następującą hipotezę: im większe są dysproporcje pomiędzy rozpiętościami dla dochodów $\mathrm{z}$ dopłatami i bez dopłat, tym większą rolę odgrywają dopłaty w kształtowaniu wyniku ekonomicznego.

W drugim etapie badań dokonano analizy porównawczej dla oceny wpływu dopłat z WPR na zrównoważenie ekonomiczne gospodarstw rolnych o różnej sile ekonomicznej dla krajów UE-15 i UE-8. Gospodarstwa podzielono na sześć klas produkcji standardowej $\mathrm{SO}^{8}$. W porównaniach zastosowano dwa warianty, podobnie jak wyżej. W pierwszym obliczono relacje dochód $\mathrm{z}$ gospodarstwa rolnego $\mathrm{z}$ dopłatami do dochodów pozarolniczych, w drugim uwzględniono dochody bez dopłat wskazując na rozpiętości. We wnioskowaniu przyjęto, że podobny wpływ dopłat z WPR na zmianę relacji dochodów rolniczych do wynagrodzenia w gospodarce narodowej względem takiej relacji w $2005 \mathrm{r}$. w różnych klasach ekonomicznych gospodarstw świadczy o tym, iż żadna z tych klas nie była uprzywilejowana $\mathrm{w}$ zakresie wpływu dopłat na zrównoważenie ekonomiczne, co przemawiałoby jednocześnie za zrównoważeniem społecznym samego rolnictwa (jako, że jednym z elementów zrównoważenia społecznego jest równomierny rozkład dochodów w badanej grupie). Tym samym asymetryczny wpływ dopłat na zrównoważenie ekonomiczne różnych klas gospodarstw oznacza brak zrównoważenia społecznego gospodarstw rolnych.

\section{Wyniki i dyskusja}

Uwzględnienie wartości dopłat z WPR powodowało, że dochody rolnicze w latach 2005-2015 stanowiły średnio 62\% przeciętnych dochodów w gospodarkach narodowych krajów UE. W krajach UE-15 relacja ta była wyższa o 14 punktów procentowych niż w krajach UE-8 (zob. tab. 1). Niezależnie od tego jednak, czy kraj należy do UE-15, czy UE-8 brak wsparcia w ramach polityki rolnej w UE powodowałby, że średnio biorąc koszty w rolnictwie unijnym przewyższałyby przychody, a więc rolnictwo byłoby działalnością nierentowną. Jest to jeden z kluczowych argumentów za utrzymaniem wsparcia sektora rolnego w UE (por. Czyżewski i Stępień, 2011). Jednocześnie należy zauważyć, że biorąc pod uwagę wartości średnie, rentowność rolnictwa w krajach przystępujących do UE w 2004 r., a tym samym jego zrównoważenie ekonomiczne, w latach 2005-2015 bardziej zależały od unijnego wsparcia niż to było w przypadku rolnictwa krajów UE-15. Świadczą o tym rozpiętości pomiędzy dochodami rolniczymi i pozarolniczymi - w UE-8 różnice te są wyższe dla dochodów rolniczych bez dopłat, zaś po ich uwzględnieniu bardziej zbliżają się do dochodów pozarolniczych aniżeli w UE-15. Jednocześnie zróżnicowanie w tym zakresie pomiędzy krajami UE-8 było większe niż w UE-15. Państwami, których rolnictwo najbardziej zyskało na wsparciu z WPR (w sensie dochodowym), w latach 2005-2015, były Słowenia i Czechy, czyli kraje o relatywnie dużych powierzchniowo gospodarstwach

\footnotetext{
${ }^{8}$ Wielkość ekonomiczna gospodarstwa rolnego wyrażana jest w jednostkach produkcji standardowej (SO Standard Output) i jest to średnia z 5 lat roczna wartość produkcji określonej działalności roślinnej lub zwierzęcej uzyskiwana z 1 ha lub od 1 zwierzęcia, w przeciętnych dla danego regionu warunkach.
} 
rolnych (okazuje się bowiem, że głównymi beneficjentami dopłat WPR są wielkotowarowe farmy, co zostanie wykazane w dalszej części publikacji). Najmniej na wsparciu z WPR zyskały natomiast gospodarstwa reprezentatywne z Polski. Spośród krajów UE-15 najbardziej na wsparciu skorzystały gospodarstwa rolne z krajów skandynawskich Finlandii, Szwecji i Danii, najmniej natomiast Włochy, Grecja, Portugalia i Hiszpania.

Tabela 1. Porównanie dochodów rolniczych gospodarstw EUFADN do dochodów pozarolniczych w krajach UE, z uwzględnieniem podziału na kraje UE-15 i UE-8, w latach 2005-2015

Table 1. Comparison of EUFAND farm incomes to non-agricultural incomes in the EU countries, including the division into EU-15 and EU-8 countries, from 2005-2015

\begin{tabular}{|c|c|c|c|c|c|c|c|c|c|c|c|c|}
\hline Lata & $\stackrel{\wp}{8}$ & ஓ̊ & ঠ̊ㅇㅇ & $\stackrel{\infty}{\stackrel{\Upsilon}{ᄋ}}$ & $\stackrel{\overbrace{}}{\stackrel{\overbrace{}}{\circ}}$ & $\stackrel{\circ}{\stackrel{\circ}{\circ}}$ & $\vec{ন}$ & 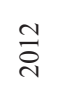 & $\stackrel{m}{\stackrel{\sim}{\sim}}$ & $\stackrel{\searrow}{\stackrel{\sim}{\curvearrowright}}$ & $\frac{n}{\stackrel{2}{c}}$ & $\frac{\cdot \frac{\pi}{Z}}{\frac{0}{0}}$ \\
\hline \multicolumn{13}{|c|}{ Relacja dochodu rolniczego $\mathrm{z}$ dopłatami WPR do dochodu pozarolniczego średnio w UE } \\
\hline & 44 & 29 & 82 & 56 & 13 & 57 & 89 & 87 & 84 & 81 & 66 & 62 \\
\hline \multicolumn{13}{|c|}{$\begin{array}{l}\text { Rozpiętości (różnice) pomiędzy dochodami pozarolniczymi a rolniczymi średnio w UE } \\
\text { (wartości w tys. EUR) }\end{array}$} \\
\hline bez dopłat & 30,3 & 36,2 & 26,5 & 34,9 & 45,2 & 36,6 & 32,8 & 30,1 & 32,2 & 35,1 & 43,3 & 34,8 \\
\hline z dopłatami & 12,9 & 16,4 & 4,3 & 9,6 & 18,0 & 9,9 & 3,2 & 2,3 & 2,8 & 5,6 & 12,5 & 8,9 \\
\hline
\end{tabular}

Relacja dochodu rolniczego $\mathrm{z}$ dopłatami WPR do dochodu pozarolniczego średnio w UE-15

\begin{tabular}{|c|c|c|c|c|c|c|c|c|c|c|c|c|}
\hline & 56 & 62 & 81 & 49 & 36 & 72 & 77 & 89 & 89 & 69 & 58 & 67 \\
\hline \multicolumn{13}{|c|}{$\begin{array}{l}\text { Rozpiętości (różnice) pomiędzy dochodami pozarolniczymi a rolniczymi średnio w UE-15 } \\
\text { (wartości w tys. EUR) }\end{array}$} \\
\hline bez dopłat & 32,9 & 32,3 & 26,1 & 35,1 & 40,7 & 32,2 & 30,9 & 27,3 & 26,4 & 33,9 & 43,8 & 32,9 \\
\hline z dopłatami & 14,5 & 12,6 & 5,4 & 13,8 & 18,1 & 9,2 & 7,3 & 2,9 & 2,5 & 10,6 & 19,5 & 10,6 \\
\hline
\end{tabular}

Relacja dochodu rolniczego $\mathrm{z}$ dopłatami WPR do dochodu pozarolniczego średnio w UE-8

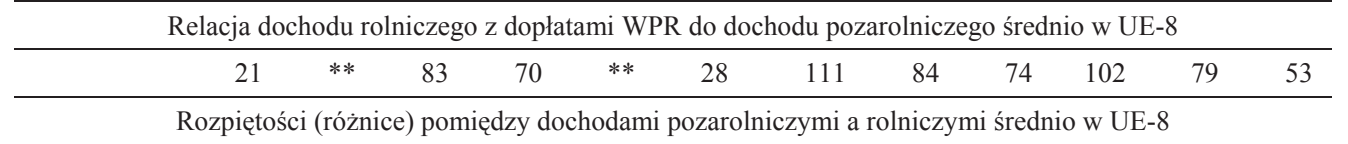
(wartości w tys. EUR)

\begin{tabular}{lrrrrrrrrrrrr}
\hline bez dopłat & 27,7 & 40,0 & 27,0 & 34,7 & 49,8 & 41,0 & 34,6 & 32,9 & 38,1 & 36,3 & 42,7 & 36,8 \\
z dopłatami & 11,2 & 20,1 & 3,3 & 5,4 & 18,0 & 10,7 & $-0,9 *$ & 1,7 & 3,1 & 0,5 & 5,6 & 7,2 \\
\hline
\end{tabular}

*wartość ujemna oznacza, że w tym roku dochód rolniczy na osobę (FWU) był o 887 euro wyższy od dochodu pozarolniczego; **2006 i 2009 nie jest uzupełniony ze względu na ujemne dochody rolnicze pomimo dopłat z WPR.

Źródło: opracowanie własne na podstawie danych bazy EUFADN, http://ec.europa.eu/agriculture/rica/, data dostępu: 08.12.2017.

Na podstawie obserwacji danych można podkreślić, że dzięki subwencjom WPR przeciętne dochody gospodarstw rolnych w poszczególnych krajach UE zbliżały się do wartości przeciętnych dochodów $\mathrm{w}$ gospodarkach narodowych, co $\mathrm{z}$ całą pewnością korzystnie wpływało na zrównoważenie ekonomiczne rolnictwa w UE (por. BaerNawrocka, 2013; Drygas, 2010). Jest to szczególnie widoczne w kryzysowym roku 2009, kiedy to rozpiętość pomiędzy średnim wynagrodzeniem w gospodarce a dochodem $\mathrm{z}$ rolnictwa wynosiłaby ponad 45 tys. euro. Dzięki wsparciu różnica ta zmniejszyła się do 18 tys. euro (zob. tab. 1). Warto też zauważyć, że w krajach UE-8 wartości relacji dochodów 
rolniczych z dopłatami do pozarolniczych dla drugiej połowy analizowanego okresu były przeciętnie wyższe niż dla początku szeregu czasowego, co może wynikać ze wzrostu poziomu wsparcia $\mathrm{w}$ ramach tzw. phasing-in (dochodzenia do pełnych płatności) w kolejnych latach po akcesji do UE. Z dużym prawdopodobieństwem można też przyjać, że w części państw UE-8 (głównie republik nadbałtyckich) relacje te będą poprawiać się w kolejnych latach, ponieważ skutecznie lobbowały one na rzecz bardziej sprawiedliwej dystrybucji dopłat bezpośrednich po 2013 r. (Swinnen, 2015).

Tabela 2. Porównanie dochodów pozarolniczych do rolniczych dla różnych klas wielkości ekonomicznej (SO) gospodarstw rolnych w UE średnio w latach 2005-2015

Table 2. Comparison of non-agricultural incomes to EUFAND farm incomes for different economic classes (SO) of farms in the EU from 2005-2015 (on average)

\begin{tabular}{|c|c|c|c|c|c|}
\hline $\begin{array}{c}\text { Klasy ekonomiczne } \\
\text { gospodarstw (tys. euro SO) }\end{array}$ & $8-25$ & $25-50$ & $50-100$ & $100-500$ & Powyżej 500 \\
\hline \multicolumn{6}{|c|}{ Relacja dochodu rolniczego z dopłatami WPR do dochodu pozarolniczego średnio w UE } \\
\hline & 29,39 & 48,45 & 84,81 & 185,72 & 15159,29 \\
\hline \multicolumn{6}{|c|}{ Rozpiętości (różnice) pomiędzy dochodami pozarolniczymi a rolniczymi średnio w UE (wartości w EUR) } \\
\hline bez dopłat & 26697 & 27451 & 25456 & 33157 & 363372 \\
\hline z dopłatami & 16114 & 12968 & 4937 & $-19535^{*}$ & $-285738 *$ \\
\hline \multicolumn{6}{|c|}{ Relacja dochodu rolniczego $\mathrm{z}$ dopłatami WPR do dochodu pozarolniczego średnio w UE-15 } \\
\hline & 21,17 & 36,38 & 63,75 & 113,84 & 232,25 \\
\hline \multicolumn{6}{|c|}{ Rozpiętości (różnice) pomiędzy dochodami pozarolniczymi a rolniczymi średnio w UE (wartości w EUR) } \\
\hline bez dopłat & 36027 & 36759 & 31850 & 24899 & 7666 \\
\hline z dopłatami & 21438 & 20097 & 12730 & $-2676^{*}$ & $-38403 *$ \\
\hline \multicolumn{6}{|c|}{ Relacja dochodu rolniczego z dopłatami WPR do dochodu pozarolniczego średnio w UE-8 } \\
\hline & 39,96 & 69,59 & 124,31 & 320,49 & 3549,86 \\
\hline \multicolumn{6}{|c|}{ Rozpiętości (różnice) pomiędzy dochodami pozarolniczymi a rolniczymi średnio w UE (wartości w EUR) } \\
\hline bez dopłat & 17368 & 18144 & 19062 & 41416 & 719079 \\
\hline z dopłatami & 10790 & 5839 & $-2857 *$ & $-36394 *$ & $-533073 *$ \\
\hline
\end{tabular}

*podobnie jak w tabeli 1, wartości ujemne oznaczają, że dochody rolnicze po uwzględnieniu dopłat były wyższe aniżeli średnie wynagrodzenie w gospodarce narodowej.

Źródło: opracowanie własne na podstawie danych bazy EUFADN (http://ec.europa.eu/agriculture/rica/, data dostępu: 08.12.2017).

Jeśli idzie o podział gospodarstw rolnych na klasy ekonomiczne, dzięki dopłatom z WPR we wszystkich klasach ekonomicznych ${ }^{9}$ średnie dochody dla lat 2005-2015 były dodatnie, przy czym relacja tych dochodów do pozarolniczych była bardzo zróżnicowana od niecałych $30 \% \mathrm{w}$ klasie 8-25 tys. euro SO do ponad $1500 \% \mathrm{w}$ klasie powyżej 500 tys. euro. Widać jednocześnie, że uwzględnienie dopłat w najwyższym stopniu sprzyjało poprawie sytuacji ekonomicznej największych podmiotów. W ich przypadku różnica pomiędzy średnim wynagrodzeniem w gospodarce a dochodem rolniczym bez dopłat sięgała 363,3 tys. euro, zaś po dodaniu subwencji dochód rolniczy przewyższał przeciętne wynagrodzenie o 285,7 tys. euro (zob. tab. 2). Generalnie można stwierdzić, że im większa

\footnotetext{
${ }^{9} \mathrm{~W}$ tabeli nie zamieszczono klasy gospodarstw najmniejszych (do 8 tys. EUR SO), ponieważ dane dla tych gospodarstw były dostępne tylko dla siedmiu krajów UE.
} 
produkcja gospodarstwa, określająca jego przynależność do danej klasy ekonomicznej, tym większy był korzystny wpływ dopłat $\mathrm{z}$ WPR na zrównoważenie ekonomiczne. Charakterystyczne jest również to, że w krajach UE-8 rola dopłat w kształtowaniu wyników dużych gospodarstw była zdecydowanie większa niż w krajach UE-15. Podobne wyniki otrzymał Matthews (2016), z którego badań wynika, iż nierówności w alokacji wsparcia pomiędzy małymi i dużymi producentami rolnymi były większe dla nowych państw członkowskich, w tym przede wszystkim Bułgarii i Rumunii. W krajach tych duże farmy były uzależnione od wsparcia w znacznie wyższym stopniu niż małe gospodarstwa.

Tabela 3. Udział dopłat WPR w dochodach gospodarstw rolnych różnych grup wielkości ekonomicznej (SO) średnio w 2005-2015 oraz zmiana tego udziału w badanym okresie.

Table 3. The share of CAP subsidies in incomes of different economic classes (SO) of farms in 2005-2015 (on average) and change of this share in the examined period.

\begin{tabular}{|c|c|c|c|c|c|}
\hline \multirow{2}{*}{ Udział dopłat } & \multicolumn{5}{|c|}{ Klasa ekonomiczna gospodarstw (tys. euro SO) } \\
\hline & $8-25$ & $25-50$ & $50-100$ & $100-500$ & pow. 500 \\
\hline \multicolumn{6}{|c|}{ UE } \\
\hline Udział dopłat w dochodzie rolniczym średnio 2005-2015 & $139 \%$ & $233 \%$ & $117 \%$ & $190 \%$ & $563 \%$ \\
\hline Zmiana udziału dopłat w dochodzie 2015/2005 & $+10 \%$ & $-4 \%$ & $-15 \%$ & $+110 \%$ & $+5 \%$ \\
\hline \multicolumn{6}{|c|}{ UE-15 } \\
\hline Udział dopłat w dochodzie rolniczym średnio 2005-2015 & $160 \%$ & $270 \%$ & $96 \%$ & $91 \%$ & $685 \%$ \\
\hline Zmiana udziału dopłat w dochodzie 2015/2005 & $-5 \%$ & $-13 \%$ & $+14 \%$ & $+5 \%$ & $+105 \%$ \\
\hline \multicolumn{6}{|c|}{ UE-8 } \\
\hline Udział dopłat w dochodzie rolniczym średnio 2005-2015 & $114 \%$ & $167 \%$ & $137 \%$ & $377 \%$ & $380 \%$ \\
\hline Zmiana udziału dopłat w dochodzie 2015/2005 & $+44 \%$ & $+23 \%$ & $-43 \%$ & $+305 \%$ & $-66 \%$ \\
\hline
\end{tabular}

Źródło: opracowanie własne na podstawie danych bazy EUFADN (http://ec.europa.eu/agriculture/rica/, data dostępu: 08.12.2017).

Poziom zróżnicowania wpływu wsparcia na zrównoważenie ekonomiczne można ukazać także poprzez określenie udziału dopłat w dochodach rolniczych. I tak, niezależnie od długości przynależności do UE, zdecydowanie najwyższy udział wsparcia średnio dla lat 2005-2015 zanotowano w przypadku gospodarstw największych (zob. tab. 3). Warto również podkreślić, że w krajach UE-8 dla wyższych klas gospodarstw wyższy był udział dopłat $\mathrm{z}$ WPR $w$ dochodzie rolniczym. Wyjątek w tym zakresie stanowią jedynie gospodarstwa od 25-50 tys. EUR SO. Zależność taka nie występuje w krajach UE-15. Jednocześnie na poziomie całej UE udział dopłat w dochodzie w stopniu największym przyrósł wśród gospodarstw z klasy 100-500 tys. euro SO, spadł zaś dla grupy 25-50 tys. euro i 50-100 tys. euro. W podziale na grupy krajów, w UE-15 najbardziej wyraźny wzrost udziału dopłat w dochodzie odnotowały największe jednostki, w UE-8 klasa 100-500 tys. euro.

\section{Podsumowanie}

$\mathrm{Na}$ podstawie przeprowadzonych analiz Autorzy dowiedli, że dzięki funduszom wspólnej polityki rolnej przeciętne dochody gospodarstw rolnych we wszystkich klasach ekonomicznych SO zbliżają się do przeciętnych dochodów sektora nierolniczego, co 
potwierdza teze o korzystnym wpływie WPR na zrównoważenie ekonomiczne sektora rolnego. Zróżnicowany był jednak łączny wpływ subwencji unijnych na wyniki dochodowe gospodarstw - w największym stopniu zyskały gospodarstwa najsilniejsze. Mówiąc inaczej, w miarę wzrostu siły ekonomicznej gospodarstwa wpływ dotacji WPR na zbliżanie się do poziomu dochodu pozarolniczego był mocniejszy. Było to efektem nierównomiernej dystrybucji wsparcia pomiędzy różne grupy producentów rolnych - większość pieniędzy trafiła do podmiotów wielkotowarowych. A zatem wspólna polityka rolna nie była instrumentem służącym wyrównywaniu dochodów wewnątrz sektora rolnego, w tym sensie nie równoważyła go społecznie (por. Bournaris i Manos, 2012). Te wyniki są spójne z wnioskami badań Bereżnickiej (2011), według których różnice w wysokości dochodów między różnymi grupami gospodarstw są duże, przy czym na ich wysokość wpływały tylko poziomy dopłat, ale także dysponowanie przez najsilniejsze gospodarstwa zasobami umożliwiającymi osiaganie wysokich poziomów produkcji. Autorka wykazała również, że w gospodarstwach bardzo dużych występuje silna współzależność jednokierunkowa pomiędzy wartością dochodu a dopłatami. Na stały wzrost nierówności dochodowych wskazuje również Szarfenberg (2015), co wynika z systemu naliczania dopłat: większe gospodarstwa otrzymują większe dopłaty, zaś niewielkie pozyskują symboliczne kwoty. Rezultatem jest przyjęta proporcja pomiędzy skumulowanym udziałem beneficjentów a skumulowaną wielkością przejętych transferów z budżetu UE określona jako 80/20. Oznacza to, że $80 \%$ najsłabszych ekonomicznie gospodarstw rolnych w UE otrzymuje $20 \%$ łącznych środków na subwencje WPR, a $\mathrm{z}$ drugiej strony - 20\% najsilniejszych przechwytuje 80\% wsparcia (por. European Commission, 2016; Velazquez, 2008). Matthews (2016) z kolei wskazuje, że dla gospodarstw FADN 20\% najsilniejszych beneficjentów przejmuje ok. $65 \%$ dopłat bezpośrednich, a $10 \%$ najsilniejszych ekonomicznie (tj. 750 tys. gospodarstw z 5 mln gospodarstw FADN) otrzymuje 45\% takiego wsparcia. Niższa asymetria w tym przypadku wynika z faktu, że badaniem objęto gospodarstwa FADN, czyli te relatywnie silniejsze ekonomicznie, stąd mniejsze dysproporcje w podziale subwencji.

Biorąc powyższe pod uwagę przyszłe reformy wspólnej polityki rolnej powinny iść w kierunku podtrzymania wsparcia dla sektora, jeśli idzie o wolumen przepływów finansowych, zmienione natomiast powinny być systemy dystrybucji pieniędzy. Dotyczy to przede wszystkim „starych” krajów UE (ale także np. Czech i Słowacji), w przypadku których relatywnie wysokie wsparcie dla dużych gospodarstw rolnych zaczyna demotywować do podnoszenia produktywności (por. Czyżewski, 2017). W tej sytuacji finansowanie budżetowe staje się zmienną decyzyjną w rachunkach opłacalności i optymalizacji i niejako „rozleniwia” kierujących gospodarstwami rolniczymi. Być może dlatego dla państw UE-15 stagnacja $w$ dochodach na jednostkę siły roboczej AWU występuje już od połowy lat 90., pomimo spadku nakładów pracy (Madre, 2016). W odniesieniu do państw UE-12 sytuacja jest przeciwna, co według Autorów może być wynikiem luki w wydajności produkcji rolnej pomiędzy „,nowymi” i „starymi” członkami UE. Rolnictwo nowych państw członkowskich wciąż ma duży potencjał wzrostu wydajności, podczas gdy w krajach UE-15 osiagnęło górny pułap i w pewnym sensie zatrzymało się w rozwoju (albo przynajmniej rozwija się wolniej niż ich otoczenie).

Poza przepływami pomiędzy krajami istotna jest alokacja środków pieniężnych wewnątrz państw w kierunku większych transferów do mniejszych jednostek. Co prawda w ramach WPR na lata 2014-2020 zaproponowano pewne rozwiązania mające na celu bardziej równomierną dystrybucję płatności bezpośrednich, ale w praktyce okazały się one 
nieskuteczne, również dlatego, iż ich wdrożenie było fakultatywne dla państw członkowskich. W przypadku tzw. degresywności/cięcia (degressivity/capping) dopłat ${ }^{10}$ w roku 2015 redystrybuowano zaledwie $109 \mathrm{mln}$ euro, co stanowi znacznie poniżej 1\% łącznych środków na I filar WPR ${ }^{11}$. Drugi z elementów - tzw. płatność redystrybucyjna ${ }^{12}$, dokonała przesunięć rzędu 1.25 mld euro, tj. ok. 3\% budżetu I filara WPR (Matthews, 2016). Wobec powyższego należy poszukiwać nowych rozwiązań w tym obszarze. Jest ku temu dobry czas, bowiem stajemy przed nową perspektywą finansową 2021-2026. Przytoczone w pracy wyniki pracy mogą stać się argumentem na rzecz efektywnej ekonomicznie, ale i bardziej sprawiedliwej dla rolników wspólnej polityki rolnej.

\section{Literatura}

Anania, G., Bartova, L. (2010). A Common Agricultural Policy for European Public Goods: Declaration by a Group of Leading Agricultural Economists. Pobrane 15 kwietnia z: www.reformthecap.eu/declaration-oncap-reform-html.

Baer-Nawrocka, A. (2013). Wpływ Wspólnej Polityki rolnej na efekty dochodowe w rolnictwie nowych krajów członkowskich (The impact of the Common Agricultural Policy on the income effects in agriculture of the new Member States). Zeszyty Naukowe SGGW w Warszawie: Polityki Europejskie, Finanse i Marketing, $9(58), 36$.

Bereżnicka, J. (2011). Dopłaty a możliwość osiągnięcia dochodu w gospodarstwach rolnych (Subsidies and the possibility of generating income on farms). Zeszyty Naukowe Uniwersytetu Szczecińskiego: Finanse, Rynki Finansowe, Ubezpieczenia, 38(640), 16-18.

Bournaris, T. Manos, B. (2012). European Union agricultural policy scenarios' impacts on social sustainability of agricultural holding. International Journal of Sustainable Development \& World Ecology, 19, 426-432.

Coleman, W.D., Tangermann, S. (1999). The 1992 CAP Reform, the Uruguay Round and the Commission: Conceptualizing Linked Policy Games. Journal of Common Market Studies, 37 (3), 385-405.

Czyżewski, A. (2007). Makroekonomiczne uwarunkowania rozwoju sektora rolnego (Macroeconomic conditions for the development of the agricultural sector). W: A. Czyżewski (red.), Uniwersalia polityki rolnej w gospodarce rynkowej. Ujęcie makro- i mikroekonomiczne (Universals of agricultural policy in a market economy. Macro and microeconomic approach) (s. 15-23). Poznań: Wyd. Akademii Ekonomicznej.

Czyżewski, A., Stępień, S. (2011). Common Agricultural Policy of the European Union in the financial perspective 2014-2020. MANAGEMENT, 1, 302-318.

Czyżewski, A., Stępień, S. (2017). Nowe uwarunkowania ekonomiczne wspólnej polityki rolnej (WPR) Unii Europejskiej (New economic conditions for the Common Agricultural Policy (CAP) of the European Union). Ekonomista, 6, 675-697.

Czyżewski, B. (2017). Kierat rynkowy w europejskim rolnictwie (Market treadmill in European agriculture). Warszawa: PWN.

Czyżewski, B., Poczta-Wajda, A. (2016). Effects of Policy and Market on Relative Income Deprivation of Agricultural Labour. Prezentacja na konferencje „160 16 th EAAE Seminar 'Rural Jobs and the CAP”, Warszawa, 1-2 grudzień 2016.

Dow, G.K., Reed, C.G. (2013). The Origins of Inequality: Insiders, Outsiders, Elites, and Commoners. Journal of Political Economy, 121(3), 609-641.

Drygas, M. (2010). Wpływ dopłat bezpośrednich w ramach Wspólnej Polityki Rolnej 2004-2006 i 2007-2013 na przekształcenia obszarów wiejskich w województwie pomorskim (The impact of direct payments under the

\footnotetext{
${ }^{10}$ Degresywność dopłat oznacza ich redukcję o minimum 5\% (aż do 100\%) koperty płatności dla gospodarstw otrzymujących powyżej 150 tys. euro rocznie. Z tego instrumentu skorzystało dziewięć państw.

${ }^{11}$ I filar WPR w przeważającej większości (ponad 90\%) obejmuje pieniądze na płatności bezpośrednie, niewielki odsetek budżetu trafia na interwencje rynkową.

${ }^{12}$ Zastosowanie mechanizmu płatności redystrybucyjnej pozwala krajom UE przeznaczyć do 30\% łącznej koperty płatności bezpośrednich dla mniejszych obszarowo gospodarstw (docelowa grupa obszarowa określana jest przez państwo). Ponieważ dystrybucja jest dokonywana poprzez redukcją całego budżetu dopłat (a nie tylko dla największych), jej wpływ na ogólną alokację pomiędzy gospodarstwa jest ograniczony. Z tego mechanizmy skorzystało osiem państw.
} 
Common Agricultural Policy 2004-2006 and 2007-2013 on the transformation of rural areas in the Pomeranian Voivodship). Ekspertyza wykonana na zamówienie Urzędu Marszałkowskiego w Gdańsku. Warszawa: Wyd. IRWiR PAN.

EUFADN (2017). Pobrane 22 kwietnia z: http://ec.europa.eu/agriculture/rica/

European Commission (2016). Report on the distribution of direct aids to agricultural producers (financial year 2015). Ref. Ares(2016)6181665 - 28/10/2016. Bruksela: Komisja Europejska.

European Parliament (2015). Comparison of Farmers' Inocmes in the EU Member States. Bruksela: DirectorateGeneral for International Policy, Parlament Europejski.

Gołasa, P. (2010). Wpływ wybranych instrumentów Wspólnej Polityki Rolnej na kształtowanie się dochodów gospodarstw rolnych w Polsce (The impact of selected instruments of the Common Agricultural Policy on the evolution of farm incomes in Poland). Zeszyty Naukowe SGGW w Warszawie: Polityki Europejskie, Finanse I Marketing, 4(53), 173-180.

Hill, B. (2012). Farm Income. W: B. Hill (red.), Wealth and Agricultural Policy: Filling the CAP's Core Informationa Gap (s. 20). Oxfordshire: CAB International.

Josling, T., Anderson, K. (2017). The EU's Common Agricultural Policy at Fifty: an Outside View. Hague: Dutch Ministry of Agriculture.

Madre, Y. (2016). The CAP: Where does the future lie?, Farm Europe: Growth. Pobrane 23 kwietnia z: http://www.farm-europe.eu/travaux/the-cap-where-does-the-future-lie $\% \mathrm{e} 2 \% 80 \% 8 \mathrm{e} /$

Marks-Bielska, R., Babuchowska, K. (2009). Wsparcie dochodów rolników w formie dopłat bezpośrednich (Support for farmers' incomes in the form of direct payments). Zeszyty Naukowe SGGW w Warszawie: Ekonomika i Organizacja Gospodarki Żywnościowej, 75, 135-148.

Matthews, A. (2016). Focus on the distribution of direct payments. Pobrane 17 kwietnia $\mathrm{z}$ : http://capreform.eu/focus-on-the-distribution-of-direct-payments/

OECD (2011). Evaluation of Agricultural Policy Reforms in the European Union, Paris: OECD Publishing. DOI: http://dx.doi.org/10.1787/9789264112124-en

Paarlberg, R. (1997). Agricultural Policy Reform and the Uruguay Round: Synergistic Linkage in a Two-Level Game? International Organization, 51(3), 413-444.

Rembisz, W. (2010). The Critical Analysis of the Intervention Basis and Evolution in Agriculture. Współczesna Ekonomia, 4(4), 7-15.

Stoeckel, A. (2000). Solving the Problem - The Political Economy of Agricultural Reform. Barton: Rural Industries Research and Development Corporation - Centre for International Economics.

Swinnen, J. (2015). The Political Economy of the 2014-2020 Common Agricultural Policy. An Imperfect Storm. London: Centre for European Policy Studies - Brussels: Rowman and Littlefield International.

Szarfenberg, R. (2015). Nierówności i ubóstwo a uczestnictwo Polski w Unii Europejskiej (Inequalities and poverty and Poland's participation in the European Union). Warszawa: Wyd. Instytut Polityki Społecznej Uniwersytetu Warszawskiego.

Wang G.C. (2009). Fundamentals of Political Economy. New York: M.E. Sharpe Inc. Publisher.

Velazquez, B. (2008). The Single Payment Scheme in the Impact Assessment of the CAP 'Health Check'. Prezentacja na konferencje "109th EAAE Seminar 'The CAP after the Fischler Reform", Vicerbo, 20-21 listopad 2008.

Zahrnt, V. (2011). A guide to CAP reform politics: issues, positions and dynamics. ECIPE Working Papers, $03 / 2011,6$

Zegar, J.S. (2010). Ekonomia wobec kwestii agrarnej (Economics in relation to the agrarian issue). Ekonomista, 6, $779-804$.

Do cytowania / For citation:

Stępień S., Guth M., Smędzik-Ambroży K. (2018). Rola wspólnej polityki rolnej w kreowaniu dochodów gospodarstw rolnych w Unii Europejskiej w kontekście zrównoważenia ekonomicznospołecznego. Problemy Rolnictwa Światowego, 18(3), 295-305; DOI: 10.22630/PRS.2018.18.3.87

Stępień S., Guth M., Smędzik-Ambroży K. (2018). The role of Common Agricultural Policy in Creating Agricultural Incomes in the European Union in the Context of Socio-Economic Sustainability (in Polish). Problems of World Agriculture, 18(3), 295-305;

DOI: $10.22630 /$ PRS.2018.18.3.87 